\title{
How Do Political and Economic News Affect Emerging Markets? Evidence from Argentina and Turkey
}

\section{Zeynep Önder \& Can Şimga-Mugan}

To cite this article: Zeynep Önder \& Can Șimga-Mugan (2006) How Do Political and Economic News Affect Emerging Markets? Evidence from Argentina and Turkey, Emerging Markets Finance and Trade, 42:4, 50-77

To link to this article: http://dx.doi.org/10.2753/REE1540-496X420403

Published online: 07 Dec 2014.

Submit your article to this journal ¿

Џ Article views: 51

Q View related articles ๘

Citing articles: 16 View citing articles 5 
Emerging Markets Finance and Trade, vol. 42, no. 4, July-August 2006, pp. 50-77.

(C) 2006 M.E. Sharpe, Inc. All rights reserved.

ISSN 1540-496X/2006 \$9.50+0.00.

DOI 10.2753/REE1540-496X420403

\title{
ZEYNEP ÖNDER AND CAN ŞIMGA-MUĞAN
}

\section{How Do Political and Economic News Affect Emerging Markets?}

\author{
Evidence from Argentina and Turkey
}

\begin{abstract}
High returns in emerging markets over the last decade have attracted international investors. This study investigates if and how economic or political news affects stock market activity in two emerging markets: Argentina and Turkey. Our analysis shows that political and economic news influences both the volatility of returns and trading volume in these markets to varying degrees. Results suggest that both economic and political factors, as well as specific market characteristics, should be taken into consideration by international investors when making investment decisions in emerging markets.
\end{abstract}

Key words: emerging markets, political and economic news, volatility and volume.

Over the last decade, the number of global stock market transactions has increased at a remarkable rate, in line with new developments in the banking and computer industries. International investors' interest in emerging markets has also grown rapidly over the same period. The share of emerging markets in world market capitalization increased from 3.7 percent in 1986 to 10.7 percent in 1995 (Rea 1996). U.S. mutual funds increased investments overseas, from $\$ 16$ billion in 1986 to $\$ 285$ billion in June 1996, about 10 percent of it in emerging market funds.

Zeynep Önder (zonder@bilknet.edu.tr) is an assistant professor in the Faculty of Business Administration, Bilkent University, Ankara, Turkey. Can Şımga-Muğan (mugan@metu .edu.tr) is a professor in the Department of Business Administration, Middle East Technical University, in Ankara, Turkey. This paper was written while Can Şımga-Muğan was on sabbatical at the State University of New York, Buffalo. The authors thank two anonymous referees and the editor for their helpful comments and suggestions. An earlier version of this paper was presented at the Annual Meetings of the European Financial Management Association, London, June 26-29, 2002.

50 
According to Rea (1996), another \$27 billion was invested in international funds in 1995, with approximately 56 percent ( $\$ 15$ billion) in emerging markets. Furthermore, total long-term capital flows to developing economies grew at an average annual rate of 15 percent over the last decade. ${ }^{1}$

The main reasons for the increased interest in emerging markets are both higher returns and a low correlation between returns in those markets and returns in developed markets. Harvey (1991) calculates that between February 1970 and May 1989 , the average cross-country correlation in seventeen developed markets was 41 percent, whereas the average cross-country correlation of emerging market returns was 12 percent. Using monthly returns from March 1986 to June 1992, Harvey (1995) finds that the average correlation between emerging and developed markets is only 14 percent-and that average returns from emerging markets are almost 50 percent higher than those from developed markets. An international financial data provider recently stated that emerging market investors enjoyed higher returns than did investors in mature markets (TrustNet News 2003). In the third quarter of 2004, as large and small capitalization stocks in the United States reflected losses of 1.9 and 2.9 percent, respectively, emerging stock markets returns saw gains of 8.3 percent (Hewitt Investment Group 2004).

Several studies (Bailey and Lim 1992; Bailey and Stulz 1990; Errunza 1983; Eun et al. 1991) have shown that the major benefit of investing in emerging markets is portfolio diversification. However, higher uncertainty in these markets relative to developed markets increases both risk and return. Two main sources of uncertainty are politics and economics. Instability in political and economic environments increases the risk of investing in these markets, and thus, investors require additional compensation for investing there.

In this study, we investigate the effects of political and economic news on stock market activity in two emerging markets: the Buenos Aires Stock Exchange (BASE) in Argentina, and the Istanbul Stock Exchange (ISE) in Turkey. Besides being two countries with rapid economic growth, they have somewhat similar economic and political environments:

- Both had major economic crisis around similar periods and applied International Monetary Fund (IMF) policies to overcome. Eichengreen (2001) defines them as two "poster boys" for the Washington consensus.

- Both countries have suffered high inflation and went through several economic sanctions to defeat hyperinflation and brought down inflation with exchange rate stablization programs and grew robustly for a period.

- Both countries were politically volatile during the last decade.

- Both economies are vulnerable to external shocks, and both depend on international financial markets.

- Both adopted official financial liberalization dates in 1989, Argentina in November and Turkey in July (Bekaert and Harvey 2000).

- Both the BASE and the ISE are highly volatile. 
- Despite volatility and risk, both stock markets have always attracted international investors. In 2000, the ISE and BASE were ranked sixth and seventh among twenty-four emerging markets that U.S. residents chose to invest in (U.S. Department of the Treasury 2005a; 2005b). In the same year, investing in Turkish and Argentine stock markets accounted for 6.38 percent and 5.38 percent, respectively, of U.S. residents' total investment in emerging markets (U.S. Department of Treasury 2005c).

- Both countries have the same overall Heritage economic index of 2.7 during the study period, between 1995 and $1997 .{ }^{2}$

We explore whether these two emerging markets react to economic and political risks similarly because of the similarities in their economic and political environments. Our aim is to investigate the effects of economic or political news on stock market indicators-specifically, return volatility and trading volume. Economic and political news items published in the Wall Street Journal and New York Times are classified as world, domestic, and country-related world news. We examine the effects of these news items on the volatility of returns and total trading volume in the BASE and the ISE between 1995 and 1997. It is found that domestic political news and world economic news increase volatility in both markets. World political news decreases trading volume in the BASE but increases it in the ISE. The results suggest a positive and significant correlation between world economic news items and volume in Argentina, and a positive association between domestic and world economic news and volume in the Turkish market.

The current study differs from previous research in two main aspects: First, it specifically investigates economic and political news in similar emerging markets. Hence, the results obtained will provide initial information about the effects of political and economic news on two comparable emerging markets. Second, it segregates economic and political news into world and domestic subcategories. Thus, the current study offers valuable insight for international investors interested in emerging markets.

\section{Background}

Turkey and Argentina are both categorized as emerging markets, and their capital markets suffered from similar problems during the same period, despite their geographic locations.

\section{Economic Conditions}

Both Turkey and Argentina suffered from trade and budget deficits from 1995 to 2000. Turkey's export deficit fluctuated from 3.31 percent of gross domestic product (GDP) ( $\$ 6$ billion) in 1996 to 1.96 percent ( $\$ 3.7$ billion) in 1997, reaching 3.52 percent of GDP in 2000. Its budget deficit also increased, from 4.64 percent of GDP in 1996 to 5.73 percent ( $\$ 11.4$ billion) in 2000. Argentina managed to con- 
trol its export deficit, bringing it down to 0.21 percent of GDP in 2000 from 0.51 percent in 1996 (World Bank 2002). It was also able to keep its budget deficit to less than 1 percent of GDP (around \$2 billion).

An excellent comparison of fiscal programs and IMF policies in Argentina and Turkey is found in Eichengreen (2001). Both countries experienced hyperinflation during the last two decades, with figures running into two and three digits. Argentina stabilized its inflation in 1991, bringing it down to almost nil. Turkey did not achieve stabilization after launching its program in 1999. As Eichengreen (2001) indicates, both countries needed capital inflows to overcome their fiscal and economic problems. Foreign direct investment in Argentina was $\$ 6.9$ billion, or 2.54 percent of GDP, in 1996; it increased to \$24 billion (8.45 percent of GDP) by 1999 , and was down to $\$ 11.7$ billion in 2000 . During the same period, Argentina's present value of debt reached $\$ 155$ billion (54.58 percent of GDP) in 2000, a year when the total debt service percentage reached 71.3 percent of exports, up from 39.5 percent in 1996. Foreign direct investment in Turkey during the same period was about only 10 percent of that of Argentina. A level of $\$ 722$ million ( 0.4 percent of GDP) in 1996 increased to \$982 million (0.49 percent of GDP) by 2000 . Turkey's present value of debt was also lower than Argentina's - $\$ 115$ billion in 2000 - but it corresponded to a higher percentage of GDP, at 57.79 percent. Although Turkey's total debt service to exports (36.1 percent) was about half that of Argentina's, its ratio of short-term debt (24 percent) was higher than Argentina's (18 percent) (World Bank 2002).

In the first half of the 1990s, Argentina privatized many of its public enterprises, eased regulations on foreign investment, and took other structural measures to improve the country's fiscal position. It thus experienced positive economic growth in this period. However, in the second half of the decade, mainly because of external shocks - such as the Mexican tequila crisis, as well as the Asian, Russian, and Brazilian crises-its growth became erratic. Argentina, Brazil, Paraguay, and Uruguay formed Mercosur, a customs union, at the beginning of 1995. The organization reflects political and military unity as well, and has become a very successful integrated market. Several developed countries, such as the United States, Canada, Spain, and other European countries, have direct foreign investment in the country, mainly in the telecommunications, oil and gas, energy, automotive, and food manufacturing industries (U.S. Department of State 2000).

In 1995, Turkey also signed a customs union agreement with the European Union as part of becoming a full member in coming years. It also launched a major privatization program in the late 1980s. However, major state economic enterprises still need to be privatized. Domestic investors still account for most privatization revenues (77.66 percent), but the contribution of international investors was very high in 1989, 1994, and 1998. ${ }^{3}$ Most of the international investors are multinational companies, operating in the cement (France), cable networking (Finland), electronics (Germany), and automotive (Italy) industries (Şımga-Muğan and Yüce 2003). 


\section{Stock Markets in Argentina and Turkey}

The BASE in Argentina and the ISE in Turkey have similar characteristics. In market capitalization, in 1995, Meridian Securities Markets ranked the BASE and the ISE thirty-sixth and fortieth, respectively, among forty-seven stock exchanges in the world. As Table 1 shows, market capitalization in the BASE increased from $\$ 3$ billion in 1990 to $\$ 170$ billion in 2000, right before the major crisis, but the number of stocks traded decreased, from 179 in 1990 to 119 in 2001 (World Federation of Exchanges 2003).

Even though the ISE is a younger market than the BASE, it developed rapidly following liberalization and opening markets to foreign investors in 1989. It has become one of the emerging markets that foreign investors favor. The number of stocks traded on the market increased from 200 in 1990 to 316 in 2000 (World Federation of Exchanges 2003), and market capitalization reached \$114 billion in 1999 , right before the crisis, from $\$ 18$ billion in 1990 (Table 1).

Empirical studies indicate that the ISE is not semistrong form efficient, and evidence on its weak-form efficiency is inconclusive (Aydoğan and Muradoğlu 1998; Muradoğlu and Ünal 1994). A recent study has checked ISE integration with developed markets, such as New York, Frankfurt, London, and Paris, and found no evidence of long-term relationships between them (Yüce and ŞımgaMuğan, 2000). It is believed that foreign investors in the ISE are institutional investors who own almost half of the stocks traded on the market, and thus have considerable control over it. In 1999, foreign holdings in the ISE were 13.4 percent of total market capitalization (Istanbul Stock Exchange 2004). Domestic investors, on the other hand, are made up of small investors who try to maximize their short-term returns with an average holding period of eight days. They have no control over the market, and believe that "large" investors "manipulate" the market, possibly through trade (Yüce et al. 1999).

Several studies have examined market efficiency in Latin America. Although some results conflict, it seems as if consensus has been reached that Argentina displays weak form efficiency and follows a random walk (Ojah and Karemera 1999). In this aspect, the BASE differs considerably from the ISE. Other studies have investigated long-term relations among Latin American stock markets, as well as their cointegration with developed markets. Chen et al. (2002) find a longterm relation among Latin American markets until 1999. In addition, the BASE is found to have a long-term relation with the U.S. market (Choudhry 1997; Seabra 2001). Meric et al. (2001) find that the correlation between U.S. and Latin American markets increased after the $1987 \mathrm{crash}$. They state that a well-diversified Latin American portfolio does not provide significantly higher returns than a welldiversified U.S. portfolio does, and suggest that investors should be selective in their approach. In sum, the markets we study differ considerably in their comovement with developed markets. 


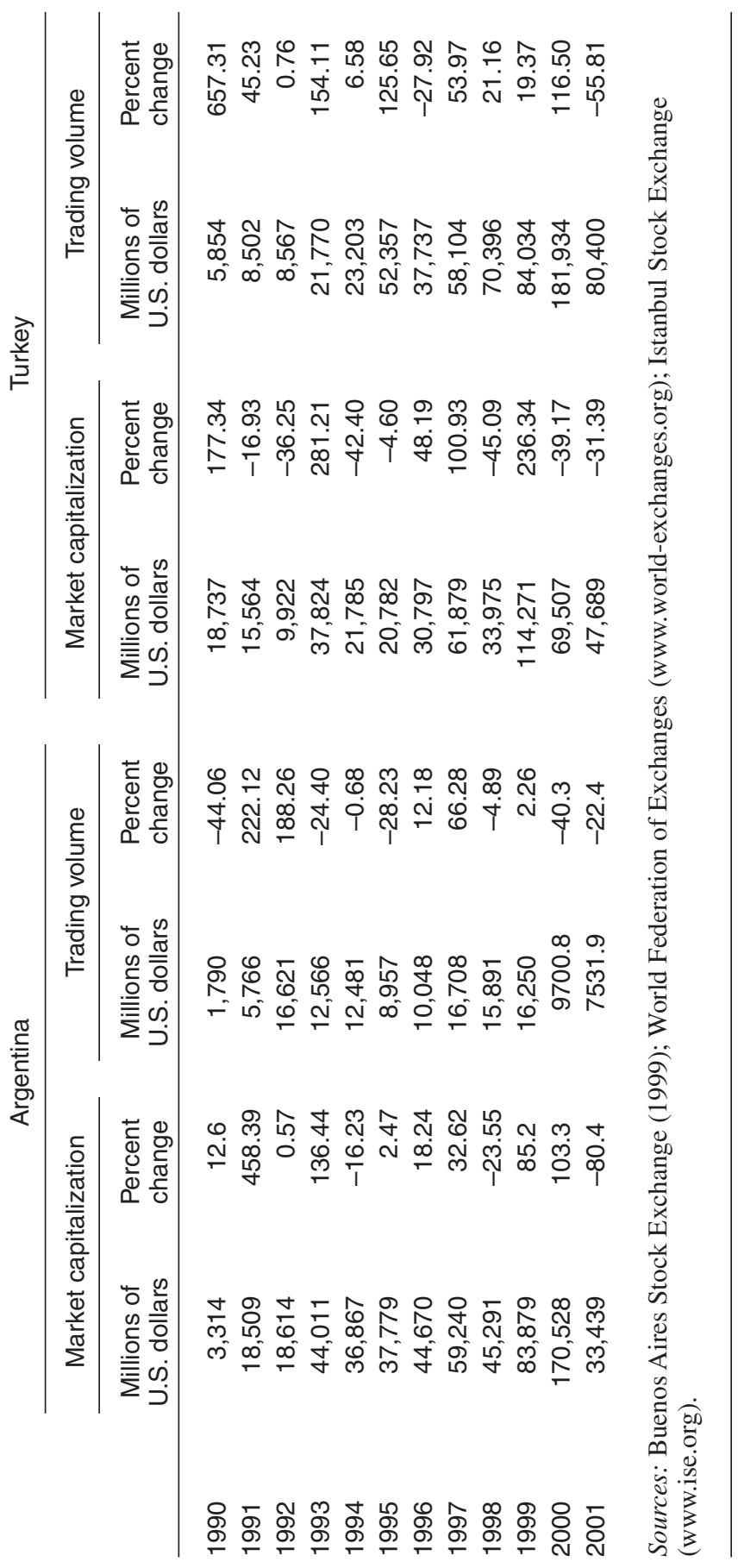




\section{Relevant Literature}

How and what kind of information stock markets process is a question that has been extensively researched in the past two decades. Most prior studies investigated the effect of several economic announcements on stock returns (Jain 1988; Mitchell and Mulherin 1994; Pearce and Roley 1985) as well as interest rate and foreign exchange markets (Ederington and Lee 1993; Tanner 1994). Harvey (1995) comprehensively analyzes twenty emerging markets, for which he forecasts returns using both world and local economic information. The results show that local information strongly influences returns in these markets.

Niederhoffer (1971) explores the effect of headline news appearing in the New York Times and the Los Angeles Times on the stock market from 1950 to 1966. The author groups headline news into various classes, and as good or bad. Examples of events are the beginning of the Korean War, the Democratic convention, the Suez crisis, the arms blockade in Cuba, President Kennedy's assassination, presidential illness, and new scientific discoveries by the United States and the Soviet Union, among others. The results indicate that large changes in stock prices can be expected following a world event. Niederhoffer states that there is a "strong tendency for large price changes on the first and second day following world events to show the same direction of change.... On Days 2-5 following extremely bad world events, there is a tendency for rises to occur... [as the] market appears to be overreacting to bad news" (1971, p. 193).

After Niederhoffer (1971), several studies have recognized that political information affects the stock market (e.g., Gartner and Wellershoff 1995; Hensel and Ziemba 1995; Herbst and Slinkman 1984; Huang 1995; Lobo 1999; Riley and Luksetich 1980). Most of these studies examine the effect of presidential and midterm elections, and the result of elections, on returns in U.S. markets, finding noticeable relations. Cutler et al. (1989) first relate the stock returns to macroeconomic indicators, then examine whether the remaining return variation can be explained by "identifiable world news" reported in the business section of the New York Times from 1941 to 1987 . The authors find the effect of such news to be "surprisingly small."

There is very limited research on the effect of political news on returns in emerging markets. Chan et al. (2001) analyze trading activities in the Hong Kong stock market before the handover period. They find that economic and political news had different effects: The former increased and the latter decreased trading activity, not only on the news arrival day, but also on the day before arrival. Moreover, economic news had a positive and significant effect on return volatility on the event day, whereas political news had a negative but insignificant effect on return volatility. Berk and Kutan (2002) investigate the effect of peace talks and violence on the Tel Aviv and Palestinian stock exchanges. They find that, although news of violence and negative negotiation news are associated with a significant decline in returns in the Tel Aviv market, only news of violence has a negative and significant 
effect on the Palestinian market. Kutan and Yuan (2002) find that political events affect stock prices in the Chinese market.

Given these findings, we aim to provide new evidence on the relative importance of economic and political news on the behavior of returns in two other emerging markets—again, Argentina and Turkey.

\section{Data}

\section{Identification of News}

Salient economic and political news are gathered from January 1995 to December 1997. Data are collected from the Wall Street Journal (WSJ), WSJ Europe, and the New York Times (NYT) to identify salient and internationally available political and economic news that international investors can easily access. We select news items in which either Turkey or Argentina were mentioned, as well as economic and political news that had global effects, as gathered from editions of the World Almanac and Book of Facts published over several years. Following Mitchell and Mulherin (1994), we try to avoid classifying the types of news that ex ante move the market, selecting only news items that influence the returns in our sample ex post.

These news items are then classified into four main groups: world economic, world political, domestic economic, and domestic political. World news is further split between those that affect the whole world and those that affect the specific country analyzed-Argentina or Turkey. The world economic (we) category includes economic news that could affect the world, as well as the specific country, such as the Asian crisis, Russian crisis, and decline in oil prices. Country-specific economic news initiated by these countries, such as issuing Eurobonds, talks with the IMF or the World Bank, foreign investments, and world news that could directly affect those countries are classified as domestic world economic (dwe) news. Similarly, world political ( $w p$ ) news includes any global political event that could affect the world, such as decisions by G-8 and G-20 countries, the war in Kosovo, or the terrorist attacks of September 11, 2001. Any political event that directly affects Turkey or Argentina, such as problems with neighboring countries or trade policies, are considered as domestic world political $(d w p)$ news. Domestic political $(d p)$ news items include election news, news of formation or dissolving of parliaments or cabinets, and statements of eminent political figures. Inflation announcements, unemployment rates, and money supply news are classified as domestic economic (de) news.

After identifying the news items-including either Turkey or Argentina from the NYT, WSJ, WSJ Europe, news indices, and news items from world almanacseach item is separately classified by each author into one of six categories stated above. The authors cross-validate each other's classification, reaching consensus for each news item. In case of disagreement, the item is dropped from the analysis. 
Table 2

Distribution of News Items by Country and Category

\begin{tabular}{lcc} 
News category & $\begin{array}{c}\text { Argentina: } \\
\text { number of } \\
\text { news items }\end{array}$ & $\begin{array}{c}\text { Turkey: } \\
\text { number of } \\
\text { news items }\end{array}$ \\
\hline Domestic political $(d p)$ & 72 & 163 \\
Domestic economic $(d e)$ & 49 & 94 \\
World political $(w p)$ & 171 & 179 \\
World economic $(w e)$ & 126 & 131 \\
Domestic world political $(d w p)$ & 81 & 158 \\
Domestic world economic $(d w e)$ & 152 & 106 \\
\hline
\end{tabular}

If an item appeared more than once in the newspapers in consecutive days, it is counted for the first occurrence only, on the assumption that investors react solely to new information. Table 2 summarizes the number of news items in each category. Although there are 189 world political and 136 world economic news items in the sample, the number of world news items is not the same in the two markets because of differences in trading days. In the sample period, the BASE has 726 trading days to the ISE's 749. Not surprisingly, the two markets also differ in the number of domestic news items: Turkey has 163 domestic political news items to Argentina's 72. Although the number of domestic world political news is higher in Turkey (158 in Turkey and 81 in Argentina), there are more domestic world economic news items in Argentina than in Turkey (152 to 106). The appendix gives some examples of news for each category. ${ }^{4}$

\section{Measures of Market Activity}

Stock market activity is measured with two variables: volatility of returns and trading volume. To calculate market volatility, we use two local stock market indices, the Merval index for the BASE and the ISE-100 index for the ISE. The Merval index is a transaction volume and value-weighted index, with a base date of June 30,1986 , and a base value of $\$ 0.01$. The composition of the index and the weights of companies included in it are adjusted quarterly based on their total trading volume in the previous six months (BASE 1999). The ISE-100 index is a float-capitalization weighted price index. ${ }^{5}$ All of the data are obtained from the databases of Datastream.

Daily returns are calculated with closing prices of two consecutive trading days,

$$
R_{i, t}=\log \left(I_{i, t} / I_{i, t-1}\right)
$$


where $R_{i, t}$ is the market return on day $t$ for country $i$, Turkey or Argentina. $I_{i, t}$ represents the level of the market index in country $i$ at the end of day $t$. Figures 1 and 2 present the index levels and total trading volume in each market between 1995 and 1997. In both markets, the indices increased in the sample period, except for the last quarter of 1997, which can be explained by the Asian crisis. The decline in the Merval index at the beginning of the sample period can be attributed to the Mexican crisis. The behavior of trading volume is slightly different from the movement of index. The daily volume fluctuated in the Argentina market over the sample period, while the daily trading volume in the Turkish market was relatively stable in 1995 and 1996. However, it started to increase in 1997, first gradually, then considerably.

Volatility is measured as the square of the deviations of daily returns from the mean daily return. Although many studies assume that mean daily returns are equal to zero and take the square of returns as a measure of volatility, we first test the hypothesis of the equality of mean daily returns to zero for the two markets. It is found that the mean daily returns are significantly different from zero for the Turkish market $(p<0.0001)$ but not for the Argentine market. To be consistent, we take the squared deviations from the mean returns in both markets. Then, volatility is calculated as the squared deviation of returns from their yearly mean to control for any yearly difference in mean returns, defined as follows:

$$
\text { Volatility }_{i, t}=\left(R_{i, t}-\bar{R}_{i Y}\right)^{2},
$$

where $\bar{R}_{i Y}$ is the mean daily return in country $i$ for year $Y, 1995,1996$, and 1997. The other market indicator is volume. It is the daily trading activity reported by Datastream for each country.

Before carrying out the analysis, we test the hypothesis of the equality of these two measures in three consecutive years, from 1995 to 1997 . We find that the median values of volatility and volume are significantly different in the three years in both markets. To control for these yearly differences, the daily values are adjusted using yearly median values as follows:

$$
\operatorname{Adjusted}\left(\text { Volume }_{i, t}\right)=\frac{\text { Volume }_{i, t}}{\text { Median }\left(\text { Volume }_{i, Y}\right)}
$$

and

$$
\left.\operatorname{Adjusted}_{\left(\text {Volatility }_{i, t}\right.}\right)=\frac{\text { Volatility }_{i, t}}{\text { Median }\left(\text { Volatility }_{i, Y}\right)} .
$$

The adjusted volatility and adjusted volume are used in the regression analysis. 
Figure 1. Merval Index and Trading Volume in the BASE for the Period Between 1995 and 1997

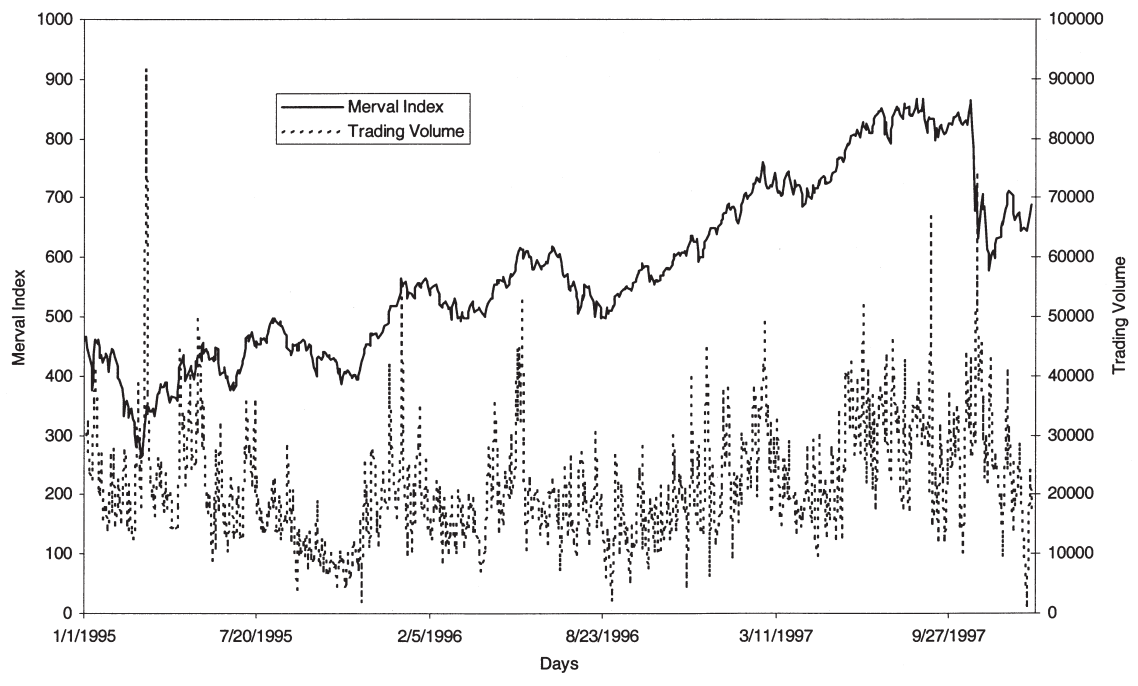

Figure 2. ISE100 Index and Trading Volume in the ISE for the Period Between 1995 and 1997

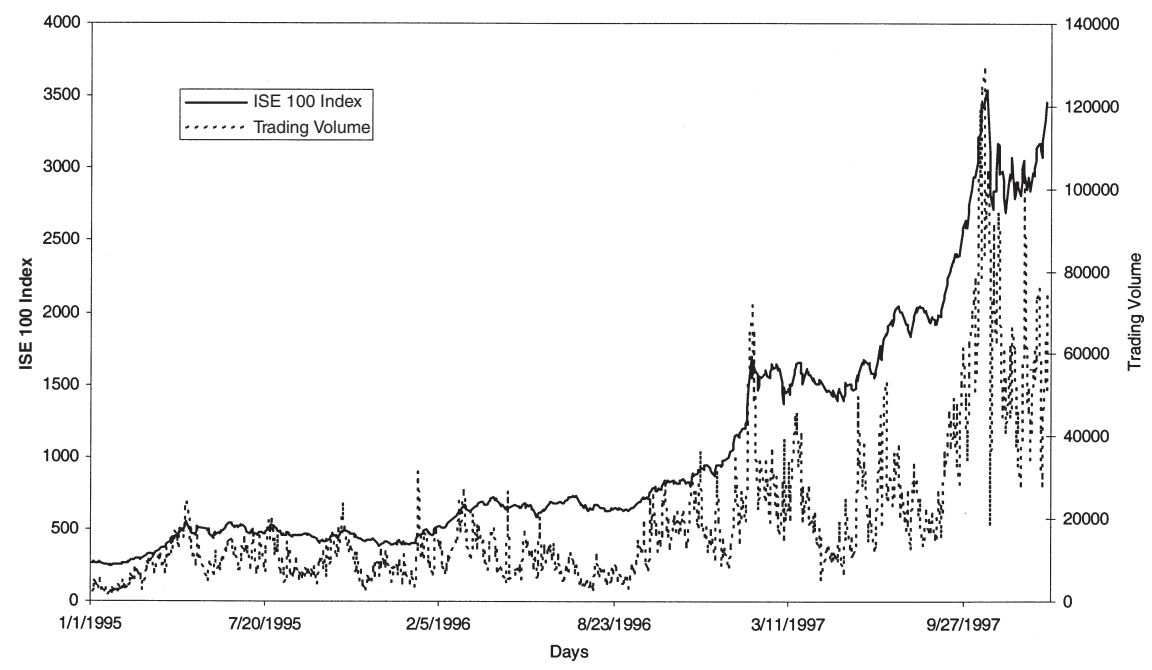




\section{Methodology}

\section{Test of Equality of Market Activity}

The equality of market activity, both volatility of returns and trading volume, is tested for news and no-news days to identify whether news items affect market activity. News days are defined as days with either global or country-related political or economic news. No-news days are those with no published political or economic global or country-specific news. The days before news is published in newspapers are excluded from the sample, because the actual event might occur on that day and the market might already be affected, even though no news is published on that day. Days in which different types of news appear at the same time are also excluded to eliminate any confounding effect.

News days are classified into two groups according to whether the news is economic or political. The equality of measures of market activity is tested for both economic and political news days. Hence, the following hypotheses are tested:

$$
\begin{aligned}
& \mathrm{H}_{01}: m_{\text {news }}=m_{\text {nonews }} \\
& \mathrm{H}_{02}: m_{\text {economic }}=m_{\text {political }} \\
& \mathrm{H}_{03}: m_{\text {economic }}=m_{\text {nonews }} \\
& \mathrm{H}_{04}: m_{\text {political }}=m_{\text {nonews }} \\
& \mathrm{H}_{05}: m_{\text {economic }}=m_{\text {political }}=m_{\text {nonews }}
\end{aligned}
$$

The median values of volatility and trading volume are used to test the equality hypothesis. Hence, the Wilcoxon sign test and the Kruskal-Wallis test are used to test whether the medians of measures of market activity are equal in two groups and three groups respectively.

\section{Regression Model}

We explore the effect of domestic, world, economic, and political news on market indicators by applying regression analyses to the entire sample between 1995 and 1997. In the regression model, explanatory variables are the number of categorized news items published in the newspapers. If no related news in that category is published, the corresponding variable takes a value of zero. All of the market indicators are regressed against these variables representing the several event categories-again, domestic political $(d p)$, domestic economic (de), world political $(w p)$, world economic (we), domestic-world political $(d w p)$, and domestic-world economic events ( $d w e$ ) specific to each country. Recall that the last two variables represent world events that directly relate to the specific country analyzed. The following model is estimated for the two markets: 


$$
\begin{gathered}
\text { Market Activity }_{t, M}=\beta_{0}+\beta_{1} d p_{t}+\beta_{2} d e_{t}+\beta_{3} w p_{t} \\
+\beta_{4} w e_{t}+\beta_{5} d w p_{t}+\beta_{6} d w e_{t}+\varepsilon_{t},
\end{gathered}
$$

where Market Activity ${ }_{t, M}$ represents the adjusted volatility and adjusted volume on day $t$ in market $M\left(M=\right.$ Turkey and Argentina). ${ }^{6}$

We have no prior expectations regarding the positive or negative effects of economic or political news on the stock market, and hence, we do not attempt to classify any news item as such. Analyzing the positive or negative effect of political and economic news is beyond the scope of this exploratory analysis.

After the model is estimated, the equality of coefficients for economic, political, domestic, world, and country-related world news is tested for each country. Based on the results of the $F$-test, new models are estimated. If there is no difference between the coefficients for domestic economic and domestic political news, and between domestic world economic and political news, but the coefficients for world political and world economic news are different, then we estimate a new model, with two variables for combined domestic news and combined countryrelated world news, as well as two different world news variables. Hence, the extended models classify news more broadly than does the first model.

\section{Empirical Results and Discussion}

Our a priori expectation is along the lines of existing literature, in that both political and economic news are valuable to investors as reflected by stock market indicators. However, we do not have any a priori expectations for the directional association between economic and political news and stock market activity.

\section{Equality of Market Activity}

Our analysis started by investigating the equality of market activity on days with no news, with only political news, and with only economic news in both markets. Although the news items covered in the total sample are allowed to happen on the same day, in this section, we wanted to examine the isolated effects of economic and political news. In so doing, we formed subsamples, in which only days with no news, with economic news, or with political news are included. If political and economic news occur on the same day, these days are excluded from the sample. In forming the subsamples, we also eliminated days with any kind of news the day before, to prevent spillover effects of news. This left us with 166 days with economic news, 162 days with political news, and 310 days with no news in Argentina; and 145 days with economic news, 217 days with political news, and 273 days with no news in Turkey (Table 3). Although the number of days with only economic news is similar in both countries, the number of days with only political news is considerably greater in Turkey during the study period between 1995 and 1997. 
Table 3

Descriptive Statistics of Volatility and Volume Measures and Tests of Equality of Their Median Values

Panel A: Descriptive statistics

\begin{tabular}{|c|c|c|c|c|}
\hline & \multicolumn{2}{|c|}{ Argentina } & \multicolumn{2}{|c|}{ Turkey } \\
\hline & Volatility $\left(10^{-4}\right)$ & Volume & Volatility $\left(10^{-4}\right)$ & Volume \\
\hline \multicolumn{5}{|l|}{ Economic } \\
\hline Median & 1.52 & 22,139 & 1.25 & 14,355 \\
\hline Mean & 4.28 & 23,692 & 6.90 & 21,265 \\
\hline Standard deviation & 7.95 & 10,701 & 18.59 & 22,438 \\
\hline$N$ & 166 & 166 & 145 & 145 \\
\hline \multicolumn{5}{|l|}{ Political } \\
\hline Median & 0.99 & 19,915 & 2.78 & 12,578 \\
\hline Mean & 5.87 & 20,666 & 7.00 & 18,564 \\
\hline Standard deviation & 14.72 & 8,716 & 11.96 & 17,097 \\
\hline$N$ & 162 & 162 & 217 & 217 \\
\hline \multicolumn{5}{|l|}{ News } \\
\hline Median & 1.24 & 20,802 & 2.26 & 13,261 \\
\hline Mean & 5.06 & 22,197 & 6.96 & 19,646 \\
\hline Standard deviation & 11.80 & 9,873 & 14.95 & 19,429 \\
\hline$N$ & 328 & 328 & 362 & 362 \\
\hline \multicolumn{5}{|l|}{ No news } \\
\hline Median & 1.18 & 19,323 & 1.88 & 12,032 \\
\hline Mean & 4.03 & 20,897 & 6.11 & 16,647 \\
\hline Standard deviation & 8.68 & 8,874 & 14.39 & 14,780 \\
\hline$N$ & 310 & 310 & 273 & 273 \\
\hline \multicolumn{5}{|c|}{ Panel B: Hypotheses testing } \\
\hline \multicolumn{5}{|l|}{ Null hypothesis } \\
\hline \multirow[t]{2}{*}{$\mathrm{H}_{01}: \mu_{\text {news }}=\mu_{\text {nonews }}$} & 0.0900 & 3.8004 & 1.9990 & 6.1308 \\
\hline & $(0.7642)$ & $(0.0512)$ & $(0.1574)$ & $(0.0133)$ \\
\hline \multirow[t]{2}{*}{$\mathrm{H}_{02}: \mu_{\text {political }}=\mu_{\text {economic }}$} & 1.2160 & 3.1129 & 6.0693 & 1.3882 \\
\hline & $(0.2702)$ & $(0.0777)$ & $(0.0138)$ & $(0.2387)$ \\
\hline \multirow[t]{2}{*}{$\mathrm{H}_{03}: \mu_{\text {economic }}=\mu_{\text {nonews }}$} & 1.0564 & 6.2398 & 0.5162 & 4.6456 \\
\hline & $(0.3040)$ & $(0.0125)$ & $(0.4725)$ & $(0.0311)$ \\
\hline \multirow{2}{*}{$\mathrm{H}_{04}: \mu_{\text {political }}=\mu_{\text {nonews }}$} & 0.6002 & 0.9379 & 4.3666 & 0.6686 \\
\hline & $(0.4385)$ & $(0.3328)$ & $(0.0367)$ & $(0.4135)$ \\
\hline $\mathrm{H}_{05}: \mu_{\text {political }}=\mu_{\text {economic }}=$ & 1.0964 & 8.2055 & 10.2412 & 4.7962 \\
\hline$\mu_{\text {nonews }}$ & $(0.5780)$ & $(0.0165)$ & $(0.0060)$ & $(0.0909)$ \\
\hline
\end{tabular}

Notes: The hypotheses $\mathrm{H}_{01}-\mathrm{H}_{04}$ are tested using the Wilcoxon sign test. The KruskalWallis test is used to test the last hypothesis, $\mathrm{H}_{05}$. Panel B reports the test statistics and their $p$-values (in parentheses). 
The null hypotheses of the equality of market activity (hypotheses $\mathrm{H}_{01}-\mathrm{H}_{05}$ ) are tested with nonparametric tests because of nonnormality in the variables. ${ }^{7}$ The results show that in the Argentine market, there is no significant difference in medians of volatility measures among days with different categories of news, even though median volatility is higher on economic news days than it is on political news days. However, trading activity in Argentina is significantly greater on days with any kind of news, with an average trading volume of 22,197 , than on days with no news, with a mean of 20,897 $(p=0.0512)$, and the mean trading activity on the days with economic news is significantly different from the days with political news $(p=0.0777)$. Among the three categories, median trading volume is highest on days with economic news $(21,139)$, followed by days with political news $(19,915)$ and days with no news $(19,323)(p=0.0165)$. Therefore, we are able to reject to the null hypotheses that median trading volume is equal on days with economic and political news and no news, but we fail to reject the same hypothesis for volatility in Argentina.

These findings suggest that Argentine market participants react to news, especially to economic news, by changing their portfolio holdings. The significantly different median trading volume observed on economic news days suggests that market participants interpret the effect of economic news differently. Because there is disagreement on the influence of such news on prices, the result is an increase in volume.

Finding no significant differences in volatility may be attributable to the weakform efficiency depicted in the Argentine market (Ojah and Karemera 1999). Furthermore, some studies found that the Argentine market is cointegrated with other Latin markets and has a long-term relation with the New York Stock Exchange (Chen et al. 2002; Choudhry 1997; Meric et al. 2001). This might explain the lack of significant differences in the effect of economic, political, and no-news days on the price volatility. Moreover, in this study, volatility is measured using the closing prices, but the news might affect the volatility of returns during the day only. The finding of higher volume on news days than no-news days, and no significant difference in volatility on news and no-news days, is consistent with Berry and Howe (1994), who find a positive relation between news release and trading volume, and no significant relation between news and volatility of returns.

Examining market activity in Turkey reveals that volatility of returns is significantly different on days with economic, political, or no news $(p=0.006)$. Although there are significant differences between days with any kind of news and with no news, volatility on days with political news and economic news is significantly different $(p=0.0138)$, with higher returns on days with political news than on those with economic news (median standard deviation of 1.67 percent on days with political news versus 1.12 percent on days with economic news). Similarly, there is a significant difference between days with political news and days with no news $(p=0.0367)$. The low variance of returns on days with economic news ex- 
plains the failure to reject the hypothesis of the equality of variances on days with news and no news.

Trading volume in Turkey is, again, significantly different among the three categories at 10 percent, with the highest mean of volume for days with economic news $(21,265)$, followed by days with political news $(18,564)$ and days with no news $(16,647)$. The findings indicate significant differences in median trading volume between days with news and with no news $(p=0.0133)$. This difference may be explained by the high volume on economic news days. However, we fail to find any significant differences between days with economic and political news only.

Interestingly, in the Turkish case, economic news seems to influence trading activity, while political news affects price volatility. The insignificant difference observed on days with economic news can be explained by the predictability of economic news. Because they can be expected before their revelation, we do not see an effect on volatility. On the other hand, political news cannot be predicted, thereby increasing volatility. However, the observation that only economic news seems to trigger trading activity suggests that, though economic news can be estimated, there are differences in the interpretation of the effect of the news on stock prices. The investment outlook of Turkish small investors may be among the reasons for higher volatility on political news days. Most small investors view the stock market as a short-term investment option, with an average holding period of eight days (Yüce et al. 1999). Although there are influential foreign investors, foreign portfolio investment is not as large as it is in Argentina. In the absence of any long-term relation with developed markets (Yüce and Şımga-Muğan 2000) and a lower amount of foreign portfolio investments, prices may fluctuate with the trade of domestic investors, who mostly react to political news, especially in a market with a very low public float rate.

Although the volatility of the two markets is found to be different on economic and political news days, we find that, in both countries, trading volume is higher on days with economic news. Educated investors or foreign investors may be entering or leaving the market on days with economic news because of its long-term implication. Hence, the differences in their interpretation may trigger trading in both markets. This implies that short-term investors value political news, while longer-term investors act upon economic news. However, such speculation should be further examined before making any conclusive statements.

\section{Effects of Different News on Market Activity}

Table 4 reports descriptive statistics of measures of market activity on days with no news and across news categories between 1995 and 1997. Examining the number of days in each category- $d p, d e, w p, w e, d w e$, and $d w p$-reveals that world political news appeared more in the papers for both countries: 151 and 156 days 


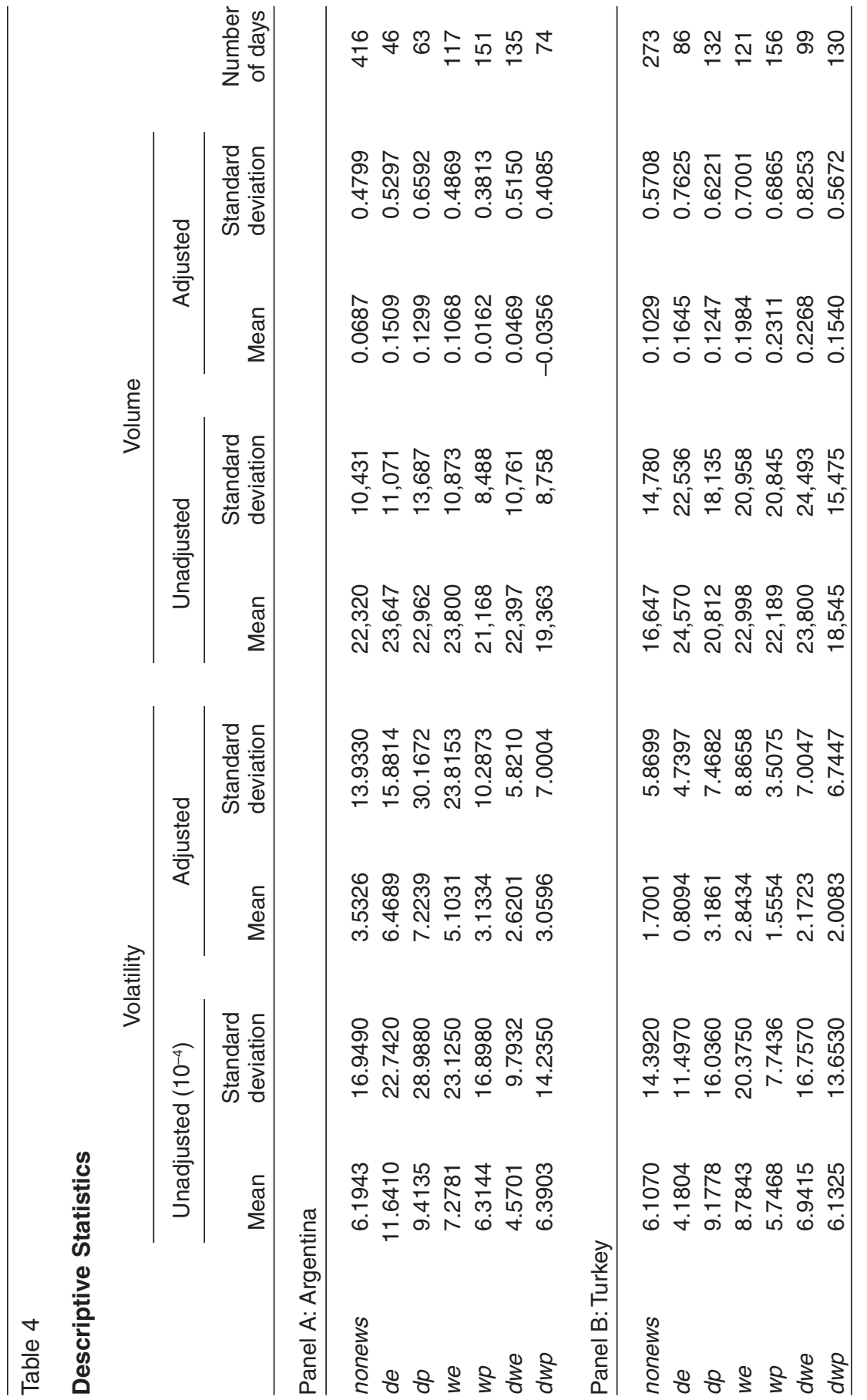


for Argentina and Turkey, respectively. For Argentina, dwe stories totaled 135 days; for Turkey, $d p$ totaled 132 days, and $d w p 130$ days. Both countries posted a very low number of days for $d e$ news, possibly because of newspaper bias.

We observe both similarities and differences between the markets. In Argentina, the highest mean volatility (unadjusted) is observed on days with domestic economic news. In Turkey, mean volatility is lowest on domestic economic news days, and highest on domestic political news days. Although mean trading volume in the BASE is very similar on news and no-news days (except $d w p$ days), in the ISE, trading volume is highest on days with domestic economic news and lowest on no-news days. The number of days is slightly different from the number of news items reported in Table 2, because more than one item in the same category may have been reported on the same day.

Table 5 provides regression results. Our model explains 8.71 percent of the variation in adjusted volatility in the Argentine market $(p<0.001)$. Domestic political $(d p)$, economic (de), and world economic (we) news significantly influence-and increase - return volatility in Argentina at significance levels of 5 or 10 percent. However, $F$-statistics testing the equality of coefficients suggest that not all types of economic and political news affect volatility equally in the BASE. Although no significant difference is found between the coefficients of domestic economic and political news and between domestic world economic and political news, the effects of world political and economic news on volatility of returns in Argentina are different. ${ }^{8}$

Even though we can explain only 1.78 percent of the variation in adjusted volume in the BASE, the model is significant at 1 percent, and reflects that world political and world economic news significantly affect the trading volume. Interestingly, trading volume declines with world political news but increases with world economic news. The decline in trading volume with world political news suggests that such news might create uncertainty in the market, and thus, investors, especially foreign investors, might hold their position until more certain information arrives. Different types of investors might perceive the effect of world economic news on the market differently, leading to an increase in trading activity. The results indicate that not all types of political news affect trading volume equally.

Although domestic news leads to fluctuations in volatility, in Argentina, volume is not affected by either domestic economic or domestic political news. Higher volatility on economic news days is in line with the findings of Chan et al. (2001), but an insignificant effect of economic news on trading activity is inconsistent. One plausible argument for this could be due to domestic small investors reacting faster to domestic political news than do international investors. The model might also be capturing individual investors with short-term orientations, as Chan et al. (2001) suggest. The content of political news might also affect institutional investors who want to avoid short-term capital losses, and thus consider exchange rate movements as well. In other words, institutional investors would like to enjoy the market returns in a foreign country as well as foreign currency appreciations. 
Table 5

Model Results with Detailed Classification

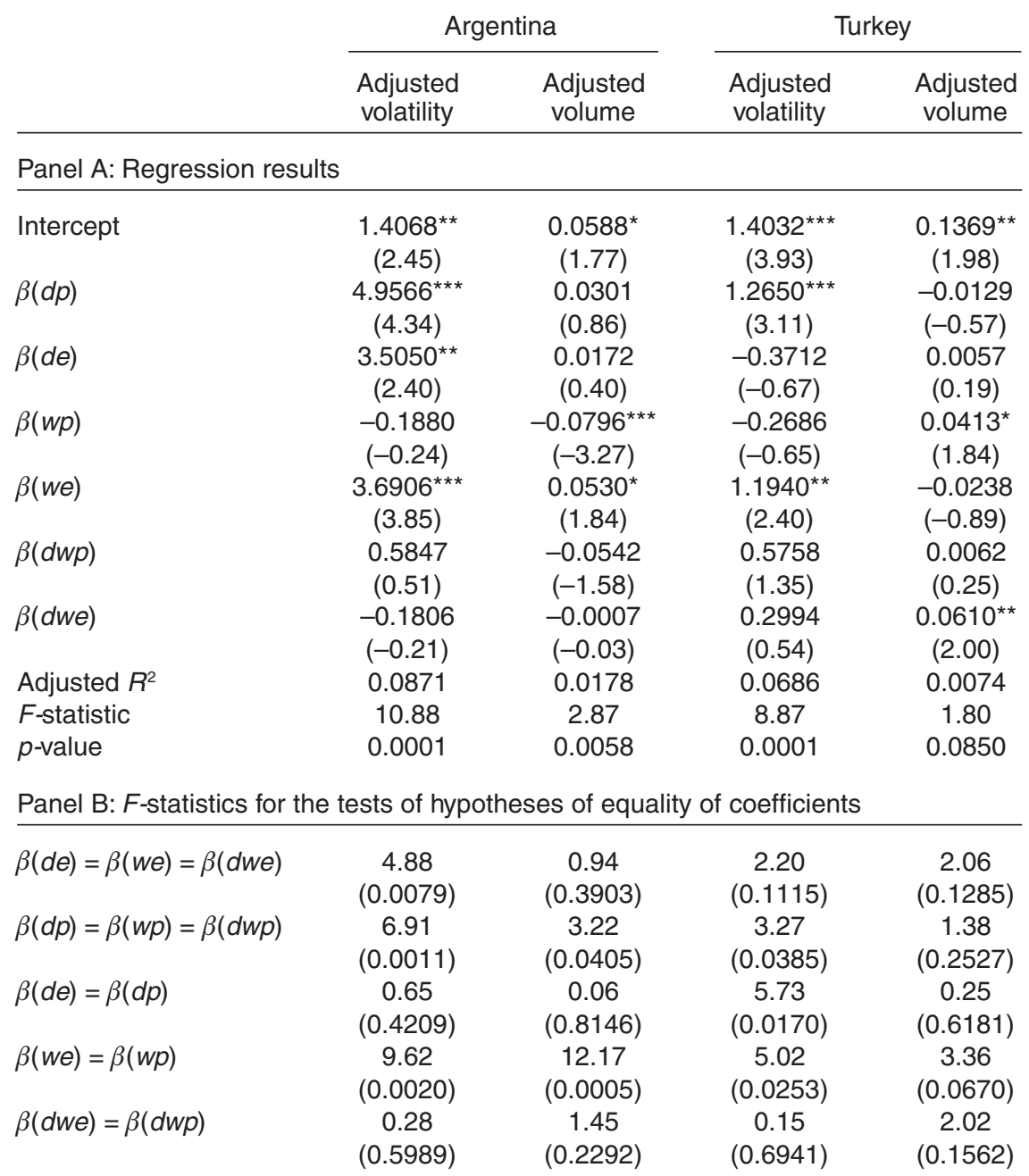

Notes: The following model is estimated for each measure of market activity, volatility and volume for each market:

$$
\text { Market Activity }{ }_{t}=\beta_{0}+\beta_{1} d p+\beta_{2} d e+\beta_{3} w p+\beta_{4} w e+\beta_{5} d w p+\beta_{6} d w e+\varepsilon,
$$

where $d p, d e, w p$, we, $d w p$, and $d w e$ represent domestic political news, domestic economic news, world political news, world economic news, country-related world political news, and country-related world economic news, respectively. In Panel A, $t$-statistics are reported in parentheses. In Panel B, $p$-values are reported in parentheses. *, **, and *** show significance at 10 percent, 5 percent, and 1 percent levels, respectively. 
On the other hand, world economic news affects both return volatility and trading volume in Argentina, at significance levels of 1 percent and 10 percent, respectively. This finding suggests that the Argentine market is integrated with world markets, because, as Bekaert and Harvey (1997) point out, world information is relatively more important for markets that are integrated into world markets. It also supports our proposition that the Argentine market is mainly affected by foreign investors, who react to world news more than the domestic news. It is quite interesting to see that world political news has a negative effect on trading volume $(p<0.01)$ and has the second lowest mean volume. We could probably speculate that international investors hold their portfolio on such days, thus causing trading volume to decrease. This connects well with our suggestion that foreign investors are large enough to control the market. The Chan et al. (2001) finding of less frequent trading on political news days in Hong Kong also supports this contention.

Similar to the Argentine market, volatility in the Turkish market increases on days with domestic political and world economic news. Unlike the BASE, ISE volatility declines on the days with domestic economic news, though it is found to be insignificant. This could be explained by the expectations of domestic investors; domestic economic news might carry less of a surprise factor than does domestic political news.

Trading volume in Turkey is significantly influenced by world political news $(w p)$ and world economic news that is closely related to the country $(d w e)$, while domestic economic news and world economic news have no significant effect. This may be due to the behavior of foreign institutional investors, who react more to such news. Such investors may pay selective attention to news that is in line with their own expectations or beliefs, as Chan (2003) suggests.

In sum, we are able to reject our null hypothesis that each category of news has a similar effect on volatility and trading activity in both markets. We find significant differences among the influences of domestic and world political and economic news. ${ }^{9}$

The common characteristics of these two markets are that the effects of world political news are different from those of world economic news in both markets (Table 5, Panel B). Moreover, the different types of political news do not seem to affect volatility equally. There are some differences between markets as well. In the BASE, different types of economic news do not have the same effect on the volatility of returns; in the ISE, we did not find any significant difference in their effects on the volatility of returns. On the other hand, domestic political news and domestic economic news do not equally affect the volatility of returns in the ISE, but the coefficients on these types of news are not found to be significantly different in the BASE.

Using the results of the tests of the equality of coefficients for each market, we developed follow-up models to test for combined effects. Because we found no difference between domestic news coefficients and between domestic world news, 
Table 6

Results of Models with Combined Variables

\begin{tabular}{|c|c|c|c|c|}
\hline & \multicolumn{2}{|c|}{ Argentina } & \multicolumn{2}{|c|}{ Turkey } \\
\hline & $\begin{array}{l}\text { Adjusted } \\
\text { volatility }\end{array}$ & $\begin{array}{l}\text { Adjusted } \\
\text { volume }\end{array}$ & $\begin{array}{l}\text { Adjusted } \\
\text { volatility }\end{array}$ & $\begin{array}{l}\text { Adjusted } \\
\text { volume }\end{array}$ \\
\hline Intercept & $\begin{array}{l}1.4057^{\star *} \\
(2.45)\end{array}$ & $\begin{array}{l}0.0593^{*} \\
(1.79)\end{array}$ & $\begin{array}{l}1.3985^{\star \star *} \\
(3.93)\end{array}$ & $\begin{array}{l}0.1379^{* *} \\
(1.99)\end{array}$ \\
\hline$\beta(d p)$ & & & $\begin{array}{l}1.2659^{\star \star \star} \\
(3.11)\end{array}$ & \\
\hline$\beta(d e)$ & & & $\begin{array}{l}-0.3636 \\
(-0.65)\end{array}$ & \\
\hline$\beta$ (domestic) & $\begin{array}{l}4.4197^{\star \star \star} \\
(4.78)\end{array}$ & $\begin{array}{l}0.0260 \\
(0.94)\end{array}$ & & $\begin{array}{l}-0.0072 \\
(-0.40)\end{array}$ \\
\hline$\beta(w p)$ & $\begin{array}{l}-0.1661 \\
(-0.21)\end{array}$ & $\begin{array}{l}-0.0807^{\star \star *} \\
(-3.32)\end{array}$ & $\begin{array}{l}-0.2525 \\
(-0.62)\end{array}$ & $\begin{array}{l}0.0371^{*} \\
(1.67)\end{array}$ \\
\hline$\beta(w e)$ & $\begin{array}{l}3.6946^{\star \star *} \\
(3.87)\end{array}$ & $\begin{array}{l}0.0552^{*} \\
(1.92)\end{array}$ & $\begin{array}{l}1.1750^{* *} \\
(2.38)\end{array}$ & $\begin{array}{l}-0.0200 \\
(-0.75)\end{array}$ \\
\hline$\beta(d w o r)$ & $\begin{array}{l}0.0443 \\
(0.07)\end{array}$ & $\begin{array}{l}-0.0215 \\
(-1.06)\end{array}$ & $\begin{array}{l}0.4734 \\
(1.40)\end{array}$ & $\begin{array}{l}0.0273 \\
(1.42)\end{array}$ \\
\hline Adjusted $R^{2}$ & 0.0885 & 0.0185 & 0.0696 & 0.0071 \\
\hline$F$-statistic & 15.07 & 3.73 & 10.33 & 2.07 \\
\hline$p$-value & 0.0001 & 0.0024 & 0.0001 & 0.0675 \\
\hline
\end{tabular}

Notes: $t$-statistics are in parentheses. $*, * *$, and $* * *$ show significance at 10 percent, 5 percent, and 1 percent levels, respectively.

but the coefficients on world economic and world political news were different for both volatility of returns and trading volume in Argentina, the following models were estimated for the BASE:

$$
\begin{aligned}
& \text { Volatility }_{t, A R}=\beta_{0}+\beta_{1} \text { domestic }_{t}+\beta_{2} w p_{t}+\beta_{3} w e_{t}+\beta_{4} \text { domestic_world }_{t}+\varepsilon_{t} \\
& \text { Volume }_{t, A R}=\beta_{0}+\beta_{1} \text { domestic }_{t}+\beta_{2} w p_{t}+\beta_{3} w e_{t}+\beta_{4} \text { domestic_world }{ }_{t}+\varepsilon_{t}
\end{aligned}
$$

The results of this regression, again, show the significant influence of domestic news and world economic news on volatility (Table 6). However, only world newspolitical and economic - has a significant effect on trading volume, at 1 and 10 percent significance levels, respectively. This finding supports the hypothesis of Bekaert and Harvey (1997) that, as the market becomes more integrated into world markets, world information becomes relatively more important. Chan et al. (2001) 
also find a negative effect of political news on trading activity. Again, this finding might be explained by the existence of institutional investors, who follow "wait and see" strategies when the information is unclear or uncertain. This might have its roots in the high transaction costs in trading in emerging markets, as Bekaert et al. (1998) suggest.

For Turkey, we estimated separate equations for volatility and volume because of the differences in the estimated coefficients:

$$
\begin{gathered}
\text { Volatility }_{t, T K}=\beta_{0}+\beta_{1} d p_{t}+\beta_{2} d e_{t}+\beta_{3} w p_{t}+\beta_{4} w e_{t}+\beta_{5} \text { domestic_world }_{t}+\varepsilon_{t} \\
\text { Volume }_{t, T K}=\beta_{0}+\beta_{1} \text { domestic }_{t}+\beta_{2} w p_{t}+\beta_{3} w e_{t}+\beta_{4} \text { domestic_world } t+\varepsilon_{t} .
\end{gathered}
$$

Both domestic political and world economic news items have a significant effect on volatility, as predicted in the first model. But only world political news has a significant effect $(p<0.10)$ on trading volume. No significant effect of countryrelated world news is found on trading volume when these types of political and economic news are combined.

The time zone difference might affect our analysis, as we use newspapers published in New York, and assume that international investors use these sources as well. News related to Turkey is published on the day international investors are expected to take positions in the ISE. News regarding Argentina is published the day after international investors might take positions in the BASE. It can thus be argued that there is a time lag between the occurrence of news events and their publication in the newspapers, as investors can take their positions the day before the news is published. Therefore, the regression model specified in Equation (1) is estimated by taking the lagged volatility and lagged volume as dependent variables. It is found that domestic political news and world economic news are significant factors affecting volatility, and domestic world political news is the only significant factor affecting volume in Argentina, but the models themselves are not found to be significant. On the other hand, world economic news is found to affect the volatility of returns, and domestic and world political news are found to significantly affect trading volume in the ISE. The significance of the coefficient on domestic political news can be explained by the reaction of domestic investors. In case of negative effects of world political news on volume, investors might prefer to follow a "wait and see" strategy.

\section{Conclusion}

This study examines the effect of political and economic news on stock market indicators in two emerging markets: Argentina and Turkey. Results suggest that political news affects the stock markets regardless of the market analyzed. In both markets, domestic political events seem to affect volatility of returns, and world political events affect trading volume significantly. However, though world politi- 
cal news affects both markets significantly, it decreases trading volume in the BASE, and increases it in the ISE. Furthermore, domestic economic news does not seem to affect the Turkish market, but it significantly increases volatility in the Argentine market. Although economic news affects volume in both markets, world economic news increases volume in the BASE, and country-related world economic news increases volume in the ISE. The differences in these findings can be explained by the involvement of foreign investors in Argentina, as well as the cointegration of the BASE with Latin American markets (Chen et al. 2002) and other world markets (Seabra 2001). In the ISE, the high trading volume is created by many small domestic investors, who usually hold stocks for rather short periods of time (Yüce et al. 1999). They also believe that returns change with no economic substance behind them, and consequently, investors become heavily tuned into domestic political news. Moreover, in a recent study, Kiymaz (2001) reports that rumors about purchases by foreign investors and earnings expectations significantly affect returns in the ISE.

Although not at the same significance level, our findings indicate that political events may also affect stock returns. An earlier study (Chan et al. 2001) found that economic news increases and political news decreases trading activity. Our results are more mixed. In the Argentine market, we observe the same effect with world news. In the Turkish market, world economic news decreases volume insignificantly, while world political news and country-related world economic news increase volume significantly. Although, at this point, we cannot be conclusive about the effect of political news, the importance of these factors should be realized and incorporated with other market characteristics when modeling stock market behavior in emerging markets. Similar studies should be carried out in other emerging markets before generalizing our results, but the present study demonstrates the need to recognize the effect of both political and economic news, as well as domestic and world news, when forming international portfolios.

Including the size of stocks in portfolios in an extended period in other emerging markets also seems appropriate at this point, because the reaction of small stocks to the news might be different from that of large stocks, and trends in these markets might display dissimilar characteristics in different periods. The stocks in each exchange can be grouped according to their size, and the analysis can be conducted separately for each size group to examine how economic and political domestic and world news affect returns of stocks of different sizes. We plan to examine the issue of size portfolios in these emerging markets over a longer time period.

\section{Notes}

1. Based on the authors' calculations using the databases maintained by the World Bank Debtor Reporting System.

2. Source: Heritage Foundation (2006) for the years 1997, 1998, and 1999, which use data from 1995, 1996, and 1997, respectively.

3. Between 1985 and 1998, total revenue from privatization was $\$ 3.535$ billion, $\$ 1.017$ 
billion of that from international investors. In 1989, 1994, and 1998, foreign investors provided \$119.45 million, \$335.87 million, and \$388.99 million, respectively (Şımga-Muğan and Yüce 2003).

4. The entire set is available upon request from the authors.

5. Float capital is the portion of the companies held by the public at a given time. The average float rate was 30.88 (31.90) percent in 1995 (1997) in Turkey (Önder 2003).

6. First, the ordinary least squares (OLS) model is estimated. Then, because of high autocorrelation, the models are estimated using generalized least squares (GLS). Before deciding on the model to be used in the estimations, three different models are estimated to test whether the intercepts and slopes are equal in each year over the three years of analysis. We fail to reject the hypothesis that the slopes have changed over the years, except for the adjusted volatility model for Argentina. To be consistent with other models, the model specified in Equation (1) is estimated for adjusted volatility in Argentina. The results of the model that takes into consideration the differences in slope coefficients in different years are discussed in footnote 7.

7. We reject the hypothesis that the unadjusted volume and volatility measures are coming from a normal distribution at a 1 percent significance level.

8. Because of differences in slope coefficients in different years, volatility of returns in the Argentine market are estimated with a model including interaction variables created with news variables and year dummy variables. Domestic economic news significantly increases volatility in 1995 and 1997, and domestic political news and world economic variables are significant in 1997.

9. These models are also estimated for the sample specified in the tests of equality of market activity. None of the coefficients are significant in the volatility model, and only the coefficient on domestic economic news items is significant in the trading volume in Argentina. All of the coefficients are found to be significant in explaining the volatility of returns, but only domestic political, world economic, and domestic world economic news items reduce volume significantly in the ISE. Because the number of observations reduces to one-third in these estimations, they are not reported, but they are available from the authors upon request.

\section{References}

Aydoğan, K., and G. Muradoğlu. 1998. "Do Markets Learn from Experience? Price Reaction to Stock Dividends in the Turkish Markets." Applied Financial Economics 8, no. 1: 41-50.

Bailey, W., and J. Lim. 1992. "Evaluating the Diversification Benefits of New Country Funds." Journal of Portfolio Management 18, no. 3: 74-80.

Bailey, W., and R.M. Stulz. 1990. "Benefits of International Diversification: The Case of Pacific Basin Stock Markets." Journal of Portfolio Management 16, no. 4: 57-61.

Bekaert G., and C.R. Harvey. 1997. "Emerging Equity Market Volatility." Journal of Financial Economics 43, no. 1: 29-78.

. 2000. "Foreign Speculators and Emerging Equity Markets." Journal of Finance 55, no. 2: 565-613.

Bekaert, G.; C.B. Erb; C.R. Harvey; and T. Viskanta. 1998. "The Behavior of Emerging Market Returns." In The Future of Emerging Market Capital Flows, ed. R. Levich, pp. 107-173. Boston: Kluwer Academic.

Berk, H.S., and A. Kutan. 2002. "Middle East Peace Process, Violence and Stock Market Development." Working Paper no. 02-0202, Southern Illinois University, Edwardville, School of Business, Economics and Finance (available at www.siue.edu/BUSINESS/ depart/econfin/facpages/kutan.htm). 
Berry, T.D., and K.M. Howe. 1994. "Public Information Arrival." Journal of Finance 49, no. 4: 1331-1346.

Buenos Aires Stock Exchange (BASE). 1999. Fact Book for the Year 1999. Buenos Aires.

Chan, W.S. 2003. "Stock Price Reaction to News and No-News: Drift and Reversal After Headlines." Journal of Financial Economics 7, no. 2: 223-260.

Chan, Y.C.; A.C.W. Chui; and C.C.Y. Kwok. 2001. "The Impact of Salient Political and Economic News on Trading Activity." Pacific-Basin Finance Journal 9, no. 3: 195-217.

Chen, G.; M. Firth; and O.M. Rui. 2002. "Stock Market Linkages: Evidence from Latin America." Journal of Banking and Finance 26, no. 6: 1113-1141.

Choudhry, T. 1997. "Stochastic Trends in Stock Prices: Evidence from Latin American Markets." Journal of Macroeconomics 19, no. 2: 285-303.

Cutler, D.M.; J.M. Poterba; and L.H. Summers. 1989. "What Moves Stock Prices?” Journal of Portfolio Management 15, no. 3: 8-12.

Ederington, L.H., and J.H. Lee. 1993. "How Markets Process Information: News Releases and Volatility." Journal of Finance 48, no. 4: 1161-1191.

Eichengreen, B. 2001. "Crisis Prevention and Management: Any New Lessons from Argentina and Turkey?" University of California, Berkeley, Department of Economics, Working Paper, October.

Errunza, V.R. 1983. "Emerging Markets: A New Opportunity for Improving Global Portfolio Performance." Financial Analysts Journal 39, no. 5: 51-58.

Eun, C.S.; R. Kolodnoy; and B.G. Resnick. 1991. "U.S. Based International Mutual Funds: A Performance Evaluation.” Journal of Portfolio Management 17, no. 3: 88-94.

Gartner, M., and K.W. Wellershoff. 1995. "Is There an Election Cycle in American Stock Returns?" International Review of Economics and Finance 4, no. 4: 387-410.

Harvey, C.R. 1991. "The World Price of Covariance Risk.” Journal of Finance 46, no. 1: $111-157$.

- 1995. "Predictable Risk and Returns in Emerging Markets." Review of Financial Studies 8, no. 3: 773-816.

Hensel, C.R., and W.T. Ziemba. 1995. "United States Investment Returns During Democratic and Republican Administrations, 1928-1993.” Financial Analysts Journal 51, no. 2: 61-69.

Herbst, A.F., and C.W. Slinkman. 1984. "Political-Economic Cycles in the U.S. Stock Market." Financial Analysts Journal 40, no. 2: 38-44.

Heritage Foundation. 2006. "2006 Index of Academic Freedom." Washington, DC (available at www.heritage.org/research/features/index/scores.cfm).

Hewitt Investment Group. 2004. "Market Perspective: Hewitt Investment Group, Fall 2004.” Atlanta (available at www.hewittinvest.com/HIG/HIGR_mark_pers.cfm?topic=MP).

Huang, R.D. 1995. "Common Stock Returns and Presidential Elections." Financial Analysts Journal 41, no. 2: 58-65.

Istanbul Stock Exchange. 2004. "Portfolio Investments in Turkey." Istanbul (available at www.ise.org/foreign/portfolio.htm).

Jain, P.C. 1988. "Response of Hourly Stock Prices and Trading Volume to Economic News." Journal of Business 61, no. 2: 219-231.

Kiymaz, H. 2001. "The Effects of Stock Market Rumors on Stock Prices: Evidence from an Emerging Market.” Journal of Multinational Financial Management 11, no. 1: 105-115.

Kutan, A., and S. Yuan. 2002. "Does Public Information Arrival Matter in Emerging Markets? Evidence from Stock Exchanges in China." Working Paper 02-0502, Southern Illinois University, Edwardsville, School of Business, Economics and Finance Department. 
Lobo, B.J. 1999. "Jump Risk in the U.S. Stock Market: Evidence Using Political Information." Review of Financial Economics 8, no. 2: 149-163.

Meric, G.; R.P.C. Leal; M. Ratner; and I. Meric. 2001. "Co-Movements of U.S. and Latin American Equity Markets Before and After the 1987 Crash." International Review of Financial Analysis 10, no. 3: 219-235.

Mitchell, M.L., and J.H. Mulherin. 1994. "The Impact of Public Information on the Stock Market." Journal of Finance 49, no. 3: 923-950.

Muradoğlu, G., and M. Ünal. 1994. "Weak-Form Efficiency in the Thinly Traded Istanbul Securities Exchange." Middle East Business and Economic Review 6, no. 2: 37-44.

Niederhoffer, V. 1971. "The Analysis of World Events and Stock Prices." Journal of Business 44, no. 2: 193-219.

Ojah, K., and K. Karemera. 1999. "Random Walks and Market Efficiency Tests of Latin American Emerging Equity Markets: A Revisit.” Financial Review 34, no. 2: 57-72.

Önder, Z. 2003. "Ownership Concentration and Firm Performance: Evidence from Turkish Firms." METU Studies in Development 30, no. 2: 181-203.

Pearce, D.K., and V.V. Roley. 1985. "Stock Prices and Economic News." Journal of Business 58, no. 1: 49-67.

Rea, J. 1996. "U.S. Emerging Market Funds: Hot Money or Stable Source of Investment Capital." Investment Company Institute Perspective 2, no. 6 (available at www.ici.org/ perspective/per02=06.pdf).

Riley, W.B., and W.A. Luksetich. 1980. "The Market Prefers Republicans: Myth or Reality." Journal of Financial and Quantitative Analysis 15, no. 3: 541-559.

Seabra, F. 2001. "A Co-Integration Analysis Between Mercosur and International Financial Markets." Applied Economics Letters 8, no. 7: 475-478.

Şımga-Muğan, C., and A. Yüce. 2003. "Privatization in Emerging Markets: The Case of Turkey." Emerging Markets Finance and Trade 39, no. 5 (September-October): 83-110.

Tanner, G. 1994. "An Note on Economic News and Intraday Exchange Rates." Journal of Banking and Finance 21, no. 4: 573-585.

TrustNet News. 2003. "Emerging Markets Still Promise Growth.” TrustNet News. Surrey, UK, June 9 (available at www.trustnet.com/general/news/display-story.asp?id=44170\& $\mathrm{db}=$ market\&txtS=y).

U.S. Department of State. 2000. "Background Note: Argentina." Bureau of Western Hemisphere Affairs, October (available at www.state.gov/r/pa/ei/bgn/26516.htm).

U.S. Department of the Treasury. 2005a. "Foreign Purchases and Sales of Long-Term Domestic and Foreign Securities by Type" (available at www.treas.gov/tic/s1_30104.txt).

. 2005b. "Foreign Purchases and Sales of Long-Term Domestic and Foreign Securities by Type" (available at www.treas.gov/tic/s1_12807.txt).

_. 2005c. "Treasury International Capital System, United States Transactions with Foreigners in Long-Term Securities, Grand Total." Washington, DC (available at www.treas.gov/tic/s1_99996.txt).

World Bank. 2002. "World Bank Key Development Data and Statistics, Country Profiles." Washington, DC (available at http://devdata.worldbank.org/data-query).

World Federation of Exchanges. 2003. "Statistics, Time Series." (available at www. world-exchanges.org/WFE/home.asp?action=document\&menu=195).

Yüce, A., and C. Şımga-Muğan. 2000. "Linkages Among Eastern European Stock Markets and the Major Stock Exchanges." Russian and East European Finance and Trade 36, no. 6 (November-December): 54-69.

Yüce, A.; Z. Önder; and C. Şımga-Muğan. 1999. “IMKB’ deki Kucuk Yatirimcilarin Tercihleri 
ve Davranislari" [Preference and Behavior of Small Investors in Istanbul Stock Exchange]. Hacettepe Universitesi, Iktisadi ve Idari Bilimler Fakultesi Dergisi 17, no. 2: 201-223.

Appendix Table A1

Some Examples of News Included in the Analysis

\begin{tabular}{|c|c|c|}
\hline Date & News type & News \\
\hline May 28, 1995 & de & Argentina privatizes two major railways \\
\hline June 17, 1995 & $d e$ & Argentina's tax revenues drop \\
\hline October 14,1996 & $d e$ & Privatization of Etibank \\
\hline December 30, 1996 & de & Turkey's trade deficit widens \\
\hline May 15, 1995 & $d p$ & $\begin{array}{l}\text { Menem wins second term as leader in } \\
\text { Argentina by a large margin }\end{array}$ \\
\hline June 14, 1995 & $d p$ & $\begin{array}{l}\text { Anti-corruption reporter shot and wounded } \\
\text { in Argentina }\end{array}$ \\
\hline January 10, 1996 & $d p$ & $\begin{array}{l}\text { Islamic Party in Turkey is asked to form } \\
\text { coalition }\end{array}$ \\
\hline December 15, 1996 & $d p$ & $\begin{array}{l}\text { Release of six Turkish soldiers to Turkey } \\
\text { opens door with Kurdish rebels }\end{array}$ \\
\hline March 26, 1995 & $\begin{array}{l}d w p \\
\text { (Argentina) }\end{array}$ & $\begin{array}{l}\text { Argentine arms sold to Ecuador during war } \\
\text { with Peru }\end{array}$ \\
\hline September 20, 1995 & $\begin{array}{l}\text { dwp } \\
\text { (Argentina) }\end{array}$ & $\begin{array}{l}\text { Britain and Argentina reach an accord on } \\
\text { Falkland oil rights }\end{array}$ \\
\hline October 8, 1996 & $\begin{array}{l}d w p \\
\text { (Turkey) }\end{array}$ & $\begin{array}{l}\text { United States criticizes Turkish leader for } \\
\text { Libya trip and trade deal }\end{array}$ \\
\hline November 28, 1996 & $\begin{array}{l}d w p \\
\text { (Turkey) }\end{array}$ & $\begin{array}{l}\text { Turkey cancels purchase of ten helicopters } \\
\text { from United States }\end{array}$ \\
\hline March 19, 1996 & $\begin{array}{l}\text { dwe } \\
\text { (Argentina) }\end{array}$ & $\begin{array}{l}\text { Pride petroleum to buy Argentina drilling } \\
\text { contractor }\end{array}$ \\
\hline December 23, 1996 & $\begin{array}{l}\text { dwe } \\
\text { (Argentina) }\end{array}$ & Argentina receives big bank credit line \\
\hline December 14, 1995 & $\begin{array}{l}\text { dwe } \\
\text { (Turkey) }\end{array}$ & $\begin{array}{l}\text { European parliament admits Turkey to its } \\
\text { new customs union }\end{array}$ \\
\hline September 5, 1996 & $\begin{array}{l}d w e \\
\text { (Turkey) }\end{array}$ & $\begin{array}{l}\text { The Overseas Economic Cooperation Fund } \\
\text { of Japan extended a loan of } 42.31 \text { billion } \\
\text { yen ( } \$ 387.2 \text { million) to Turkey to implement } \\
\text { the second phase of its Istanbul water } \\
\text { supply project }\end{array}$ \\
\hline June 8, 1995 & we & $\begin{array}{l}\text { Dollar advances on prospect of interest rate } \\
\text { cut by Germany }\end{array}$ \\
\hline November 17, 1995 & we & $\begin{array}{l}600 \text { banks agree to reschedule billions in } \\
\text { Russian debt }\end{array}$ \\
\hline March 1, 1995 & wp & $\begin{array}{l}\text { NATO disputes UN reports of possible arms } \\
\text { airlift to Bosnia }\end{array}$ \\
\hline
\end{tabular}


March 17, 1995

September 24, 1996 $w p$

wp
Clinton meets with Bosnian and Croatian chiefs

The United States and Russia have reached agreement on the first part of an understanding that would allow the United

States to proceed with efforts to build defenses against shorter-range missiles, while preserving the Anti-Ballistic Missile Treaty of 1972

Notes: $d e=$ domestic economic; $d p=$ domestic political; $d w p=$ domestic world political; $d w e=$ domestic world economic; $w e=$ world economic $; p=$ world political . 